(n)

\title{
Pushing estrogen receptor around in breast cancer
}

\author{
Elgene Lim', Gerard Tarulli², Neil Portman', Theresa E Hickey², Wayne D Tilley², and \\ Carlo Palmieri3,*
}

1Garvan Institute of Medical Research and St Vincent's Hospital, University of New South Wales, Sydney, New South Wales, Australia

2Dame Roma Mitchell Cancer Research Laboratories and Adelaide Prostate Cancer Research Centre, University of Adelaide, Adelaide, South Australia, Australia IInstitute of Translational Medicine, University of Liverpool, Clatterbridge Cancer Centre, NHS Foundation Trust, and Royal Liverpool University Hospital, Liverpool, Merseyside, UK

*(W D Tilley and C Palmieri contributed equally to this work)

Correspondence should be addressed to W D Tilley or C Palmieri Email

wayne.tilley@adelaide.edu.au or c.palmieri@liverpool.ac.uk

\begin{abstract}
The estrogen receptor- $\alpha$ (herein called ER) is a nuclear sex steroid receptor (SSR) that is expressed in approximately $75 \%$ of breast cancers. Therapies that modulate ER action have substantially improved the survival of patients with ER-positive breast cancer, but resistance to treatment still remains a major clinical problem. Treating resistant breast cancer requires co-targeting of ER and alternate signalling pathways that contribute to resistance to improve the efficacy and benefit of currently available treatments. Emerging data have shown that other SSRs may regulate the sites at which ER binds to DNA in ways that can powerfully suppress the oncogenic activity of ER in breast cancer. This includes the progesterone receptor (PR) that was recently shown to reprogram the ER DNA binding landscape towards genes associated with a favourable outcome. Another attractive candidate is the androgen receptor (AR), which is expressed in the majority of breast cancers and inhibits growth of the normal breast and ER-positive tumours when activated by ligand. These findings have led to the initiation of breast cancer clinical trials evaluating therapies that selectively harness the ability of SSRs to 'push' ER towards anti-tumorigenic activity. Our review will focus on the established and emerging clinical evidence for activating PR or AR in ER-positive breast cancer to inhibit the tumour growth-promoting functions of ER.
\end{abstract}

\section{Key Words}

- estrogen receptor

- endocrine therapy

- endocrine resistance

- breast cancer

- progesterone receptor

- androgen receptor

\section{Introduction}

There are three major sex steroid hormones - estrogen, progesterone and androgen - and each affect the signalling activity of its cognate sex steroid receptor (SSR), that is the estrogen receptor- $\alpha$ (ER), progesterone receptor (PR) and androgen receptor (AR), respectively. In women, sex steroid hormones are produced by the ovaries (and adrenal glands in the case of androgens) and through peripheral conversion of circulating precursors (Simpson 2003, Nicolas Diaz-Chico et al. 2007, McNamara et al. 2014,
McNamara \& Sasano 2015). SSRs are structurally related and evolutionarily conserved, have similar consensus DNA-binding motifs and use common co-factors for activity (Germain et al. 2006).

ER is expressed in approximately $75 \%$ of all breast cancers. When present, ER drives neoplasia and is a bona fide therapeutic target. The underlying aim of current endocrine therapy is to either reduce ER activity or reduce receptor levels within breast cancer cells.

This paper is part of a thematic review section on hormone-dependent cancers. The Guest Editor for this section was Wayne Tilley. 
Despite the success of ER-directed treatments, a significant proportion of patients with ER-positive breast cancer relapse from their cancer due to inherent or acquired resistance to endocrine therapy. It has been recently shown that endocrine resistance may be the result of genetic and epigenetic factors (Ellis et al. 2012, Fuqua et al. 2014, Jeselsohn et al. 2015, Stone et al. 2015). Gain-of-function mutations in ESR1, the gene encoding the ER, are a relatively rare event in primary breast cancer (Cancer Genome Atlas Network 2012), but can be detected using next-generation sequencing in approximately $20 \%$ of patients with metastatic ER-positive disease who had received prior endocrine therapies (Robinson et al. 2013, Toy et al. 2013, Fuqua et al. 2014, Jeselsohn et al. 2015). A higher prevalence (up to 55\%) of ESR1 mutations has been reported in circulating free DNA (cfDNA) in metastatic ER-positive breast cancers with prior AI therapy when using digital droplet PCR to increase mutation detection sensitivity (Chandarlapaty et al. 2016, Fribbens et al. 2016, Spoerke et al. 2016). These mutations cluster in the ligand-binding domain of the ER and lead to ligand-independent ER activity that promotes tumour growth, partial resistance to endocrine therapy and potentially enhanced metastatic capacity. It has also been shown that DNA hypermethylation of estrogenresponsive elements can result in reduced ER binding and decreased gene expression of key regulators of ER activity and resistance to ER-directed therapies (Stone et al. 2015).

The clinical challenge of disease recurrence after ER-directed therapy (endocrine therapy) has led to increased attention being focussed on combining endocrine therapy with novel agents that target resistance mechanisms. Although many of these novel therapies have increased the time to progression, they are not curative and the development of resistance ultimately limits their use. Therefore, further scientific and clinical research into new endocrine therapies as well as strategies to enhance the effectiveness of currently available endocrine agents are essential to improve outcomes in both early and metastatic disease. In this regard, the high level of co-expression of PR and AR in ER-positive breast cancer makes these sex steroid receptors attractive targets for broad-based therapeutic intervention. The purpose of this review is to examine the emerging evidence for inter-connected roles of ER, $\mathrm{PR}$ and $\mathrm{AR}$, and discuss how modulating PR and AR may be an effective therapeutic strategy for sex hormone receptor-positive breast cancer.

\section{ER-directed therapies and targeted combination therapies}

Current ER-directed strategies involve disrupting the process of estrogen production or modulating either the function or level of ER in breast cancer cells. In pre-menopausal women, the majority of circulating estrogen comes from the ovarian follicles, stimulated by luteinizing hormone (LH) and follicle-stimulating hormone (FSH) secreted by the anterior pituitary gland. Pituitary production of LH and FSH is controlled by secretion of GnRH (also known as luteinisinghormone-releasing hormone) from the hypothalamus. In the postmenopausal setting, estrogen production is dependent on peripheral aromatisation of circulating pro-androgens, predominantly in the liver, adrenal glands and adipose tissue. Whatever the source, estrogen exerts its effect via binding to ER, which in turn binds DNA to directly regulate the transcription of target genes. Endocrine therapy is aimed at modulating and disrupting these processes either by blocking pituitary production of LH/FSH (GnRH analogues), blocking ER (tamoxifen), degrading ER (fulvestrant) or by inhibiting the peripheral production of estrogen (aromatase inhibitors).

All women diagnosed with ER-positive BC should be considered for endocrine therapy. The introduction and widespread use of adjuvant tamoxifen and subsequently aromatase inhibitors (AIs) in the postmenopausal population has resulted in significant improvements in the overall survival of women with ER-positive early BC (Dowsett et al. 2010, Early Breast Cancer Trialists' Collaborative Group 2011). Therefore, ER-directed therapies represent a cornerstone strategy in the management of ER-positive breast cancers. In spite of this, approximately $30 \%$ of patients will experience relapse due to inherent or acquired-resistance to the above-mentioned therapies. In the metastatic setting, the introduction of sequential lines of different endocrine therapies involving aromatase inhibitors and fulvestrant has led to stepwise improvements in disease control and outcomes for women with metastatic ER-positive disease (Lonning 2000, Mehta et al. 2012, Robertson et al. 2012).

Alternative target therapies have recently been used in combination with ER-directed therapies to improve survival outcomes, representing a major advance in the treatment options for patients with metastatic ER-positive breast cancer. These include drugs that target the phosphatidylinositol-4,5-bisphosphate 3-kinase (PI3K) cell signalling pathway. One such drug, which is FDA approved for use in advanced breast cancer,

Published by Bioscientifica Ltd. 
is everolimus, an inhibitor of mammalian target of rapamycin (mTOR), which is downstream of PI3K. The combination of everolimus with ER-directed therapies has approximately doubled the duration of progressionfree survival compared with ER-directed therapies alone (Bachelot et al. 2012, Baselga et al. 2012, Piccart et al. 2014). Conversely, the addition of a pan-PI3K inhibitor to fulvestrant has demonstrated either no improvement in clinical outcome (Krop et al. 2016) or a very modest overall effect with those patients with PIK3CA mutations detectable in cell-free DNA deriving the greatest benefit (Baselga et al. 2016).

Another class of drugs that has demonstrated clinical efficacy in the treatment of metastatic breast cancer is the inhibitors of cyclin-dependent kinases 4 and 6 (CDK 4/6), which regulate cell cycle progression. Cyclin D-CDK4/6INK4-Rb pathway activation is a feature of endocrineresistance breast cancer (Thangavel et al. 2011). CCND1 gene amplification and overexpression of the cyclin $\mathrm{D}$ protein are found in a significant proportion of ER-positive breast cancer (Cancer Genome Atlas Network 2012). Co-administration of palbociclib, a CDK 4/6 inhibitor, with ER-directed therapies approximately doubles progressionfree survival compared with ER-directed therapy alone both in patients receiving first-line metastatic therapy, and patients with metastatic breast cancer that progressed on previous endocrine therapy (Finn et al. 2015, 2016, Turner et al. 2015). The results of similarly designed large phase III trials of other CDK 4/6 inhibitors, including ribociclib (Clinicaltrials.gov identifiers NCT01958021 and NCT02278120) and abemaciclib (Clinicaltrials. gov identifiers NCT02107703 and NCT02246621) in combination with endocrine therapy would be reported in the near future.

\section{PR-directed strategies for treating breast cancer}

$\mathrm{PR}$ is expressed in a large proportion of ER-positive breast cancer (Nadji et al. 2005), and elevated PR levels have been shown to correlate with increased probability of response to endocrine therapy, longer time to treatment failure, and longer overall survival, independent of ER expression (Ravdin et al. 1992, Bardou et al. 2003, Purdie et al. 2014, Koornstra et al. 2015). Multivariate analyses have demonstrated that $\mathrm{PR}$ expression is prognostic compared with biomarkers such as ER and HER2, but less so in node-negative breast cancer (Fisher et al. 1988, Cuzick et al. 2011). However, PR expression does not influence the relative benefit of adjuvant AI therapy over tamoxifen in ER-positive breast cancers (Viale et al. 2007, Early Breast Cancer Trialists' Collaborative Group 2015). ER drives the expression of PR, and this serves as a wellestablished biomarker of ER functionality. The functional role of PR in breast cancer on the other hand, has not been as extensively investigated as ER.

The use of progesterone for the treatment of breast cancer was limited by the need for intramuscular injection leading to the development of synthetic orally available progestogens (Stoll 1967). Subsequent clinical trials of the synthetic progestogens megestrol acetate (megace) and medroxyprogesterone acetate (MPA) demonstrated consistent benefit in women with advanced ER-positive breast cancer (Table 1). In the context of failure of prior endocrine therapy, median durations of response of up to 10 months have been reported (Brufman et al. 1994, Birrell et al. 1995b, Abrams etal. 1999, Bines et al. 2014). Progestins have similar efficacy to tamoxifen, oophorectomy and aminoglutethimide (an AI and inhibitor of cholesterol conversion to steroids) in comparative trials in the metastatic setting (Ingle et al. 1982, Ettinger et al. 1986, van Veelen et al. 1986, Canney et al. 1988, Muss et al. 1988, 1994, Lundgren et al. 1989, Martoni et al. 1991). An adjuvant study in high-risk breast cancer demonstrated no difference in outcomes between tamoxifen for 1 year, tamoxifen for 2 years or tamoxifen for 6 months followed by megestrol acetate for 6 months (Andersen et al. 2008). Moreover, a study of a single injection of $500 \mathrm{mg}$ of hydroxyprogesterone before surgery in postmenopausal women demonstrated an improvement in outcomes overall, with a significant improvement in patients with lymph node metastases (Badwe et al. 2011).

Interestingly, $\mathrm{AR}$ was shown to be a positive biomarker in predicting response to MPA, suggesting that its action in breast cancer may be mediated in part by $\mathrm{AR}$, or indeed that $\mathrm{AR}$ may be a key determinant of endocrine responsiveness generally (Birrell et al. $1995 b)$. In spite of the above-mentioned findings and more recent data showing that progesterone inhibits estrogen-stimulated growth in patient-derived xenograft models of ER- and PR-positive breast cancer (Kabos et al. 2012), progestogens have now been supplanted by newer therapies targeting ER alone or in combination with other emerging non-ER-directed therapies in the treatment of advanced breast cancer.

Another PR targeting strategy that has been evaluated in breast cancer is the use of PR antagonists such as mifepristone (RU486) and onapristone. Trials with these agents have been limited to small sample sizes, and the response rates have been modest

Published by Bioscientifica Ltd 
Table 1 Clinical trials using progesterone receptor agonists and antagonists in the treatment of advanced breast cancer.

\begin{tabular}{|c|c|c|c|c|}
\hline Treatment & No. of patients & Median duration of response & $\begin{array}{l}\text { Objective response and } \\
\text { clinical benefit rate }\end{array}$ & Reference \\
\hline \multicolumn{5}{|c|}{$\overline{\text { Progesterone receptor antagonists }} \overline{\text { s }}$} \\
\hline Mifepristone, 2nd/3rd line & 22 & - & $\begin{array}{l}\text { CBR: } 54 \%, 18 \% \text { after } \\
3 \text { months }\end{array}$ & Romieu et al. (1987) \\
\hline Mifepristone, 1st line & 28 & - & ORR: $10.7 \%$ & Perrault et al. (1996) \\
\hline Lonaprisan, 2nd line & 68 & - & $\begin{array}{l}\text { CBR: } 21 \%(25 \mathrm{mg}) ; \\
\quad 7 \%(100 \mathrm{mg})\end{array}$ & Jonat et al. (2013) \\
\hline \multicolumn{5}{|l|}{ Progestins } \\
\hline MPA & 52 & - & $\begin{array}{l}\text { ORR: } 43 \% \\
\text { CBR } 63 \%\end{array}$ & Pannuti et al. (1978) \\
\hline Megace, 1st/2nd line & 172 & $\begin{array}{l}\text { HD, } 8 \text { months; LD, } 3.2 \text { months } \\
\quad(P=0.019)\end{array}$ & $\begin{array}{l}\text { ORR: HD, } 27 \% \text {; } \\
\text { LD, } 10 \%(P=0.005)\end{array}$ & Muss et al. (1990) \\
\hline \multicolumn{5}{|c|}{ Progestin treatment after specific previous treatment failure } \\
\hline $\begin{array}{l}\text { Megace after TAM/AG, } \\
\text { 2nd line }\end{array}$ & 73 & 9-10 months & $\begin{array}{l}\text { ORR: } 4 \% \\
\text { CBR: } 52 \%\end{array}$ & Brufman et al. (1994) \\
\hline MPA after TAM, 2nd line & 83 & 9.7 months & ORR: $38.6 \%$ & Birrell et al. (1995b) \\
\hline $\begin{array}{l}\text { Megace after NSAI, } \\
\text { 2nd line }\end{array}$ & 48 & 10 months & $\begin{array}{l}\text { ORR: } 0 \% \\
\text { CBR: } 39.6 \%\end{array}$ & Bines et al. (2014) \\
\hline \multicolumn{5}{|c|}{ Progestins in comparative studies } \\
\hline Megace vs TAM, 1st line & 55 & MA, 65 days; TAM, 58 days & $\begin{array}{l}\text { CBR: MA, 14\%; } \\
\text { TAM, 26\%: (NS) }\end{array}$ & Ingle et al. (1982) \\
\hline Megace vs TAM, 1st line & 190 & 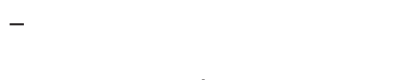 & $\begin{array}{l}\text { CBR: MA, } 35 \% \\
\text { TAM, } 42 \%\end{array}$ & Ettinger et al. (1986) \\
\hline MPA vs TAM, 1st line & 129 & $\begin{array}{l}\text { MPA, } 17 \text { months; } \\
\text { TAM, } 23 \text { months (NS) }\end{array}$ & $\begin{array}{l}\text { CBR: MPA, } 44 \% \text {; } \\
\text { TAM, 35\%: (NS) }\end{array}$ & van Veelen et al. (1986) \\
\hline MPA vs AG, 2nd line & 218 & $\begin{array}{l}\text { MPA, } 42 \text { weeks; } \\
\text { AG, } 44 \text { weeks (NS) }\end{array}$ & $\begin{array}{l}\text { ORR: MPA, 31\%; } \\
\text { AG, } 27 \% \text { (NS) } \\
\text { CBR: MPA, 54\%; } \\
\text { AG, } 51 \% \text { (NS) }\end{array}$ & Canney et al. (1988) \\
\hline Megace vs TAM, 1st/2nd line & 136 & $\begin{array}{l}\text { MA, } 7.7 \text { months; } \\
\text { TAM, } 7.7 \text { months (NS) }\end{array}$ & $\begin{array}{l}\text { ORR: MA, } 28 \% \\
\text { TAM, } 31 \%\end{array}$ & Muss et al. (1988) \\
\hline Megace vs AG, 2nd line & 150 & $\begin{array}{l}\text { MA, } 13 \text { months; } \\
\text { AG, } 13.1 \text { months }\end{array}$ & $\begin{array}{l}\text { ORR: MA, } 31 \% \\
\text { AG, } 34 \%\end{array}$ & Lundgren et al. (1989) \\
\hline $\begin{array}{l}\text { MPA vs oophorectomy, } \\
\text { 2nd line }\end{array}$ & 40 & $\begin{array}{l}\text { MPA, } 9 \text { months; } \\
\text { OPX, } 7 \text { months }\end{array}$ & $\begin{array}{l}\text { ORR: MPA, } 55 \% ; \\
\text { OPX, } 33 \%(P=0.17)\end{array}$ & Martoni et al. (1991) \\
\hline MPA vs TAM, 1st line & 166 & $\begin{array}{l}\text { MPA, } 6.3 \text { months; } \\
\text { TAM, } 5.5 \text { months }(P=0.48)\end{array}$ & $\begin{array}{l}\text { ORR: MPA, 34\%; } \\
\quad \text { TAM, } 17 \%(P=0.01)\end{array}$ & Muss et al. (1994) \\
\hline
\end{tabular}

MPA, medroxyprogesterone acetate; Megace, megestrol acetate; TAM, tamoxifen; AG, aminoglutethimidine; LD/HD, low/high Dose; OPX, oophorectomy; CBR, clinical benefit rate; ORR, objective response rate; NS, not significant.

Many clinical trials have been conducted that have studied the effects of progestins alone and in combination with other therapies in the treatment of advanced breast cancer. Table 1 presents a sample of studies accruing more than 20 patients. In general, progestins show comparable efficacy to other endocrine therapies in 1st and 2nd line treatment of advanced breast cancer.

(Romieu et al. 1987, Klijn et al. 1989, Perrault et al. 1996). Onapristone was associated with hepatic toxicity, and the study was prematurely terminated (Robertson et al. 1999). Hence, this class of therapy has not progressed to routine clinical use.

\section{Role of AR in breast cancer}

Overall, AR is the most prevalent SSR in all stages of breast cancer, occurring in up to $90 \%$ of primary tumours and $75 \%$ of metastatic breast cancer (Lea et al. 1989, Moinfar et al. 2003, Park et al. 2010, Cimino-Mathews et al. 2012, Honma et al. 2012, Ren et al. 2013). The frequency of
AR expression varies between breast cancer subtypes, with ER-positive cancers more likely to be AR-positive compared with ER-negative cancers (Gonzalez-Angulo et al. 2009, Peters et al. 2009, Micello et al. 2010, Niemeier et al. 2010, Park et al. 2010, Collins et al. 2011, Hu et al. 2011, Loibl et al. 2011, Yu et al. 2011). Some studies have reported AR expression based on luminal sub-types with luminal A cancers expressing AR more frequently than luminal B (Collins et al. 2011, Yu et al. 2011). AR and ER co-localize at select genomic loci within the nuclei of breast cancer cells (Peters et al. 2009) and AR expression in ER-positive cancers has been associated with favourable clinicopathological characteristics such

Published by Bioscientifica Ltd 
as older age at diagnosis, lower tumour grade, lower Ki-67 positivity, smaller tumours and less necrosis (Castellano et al. 2010, Hu et al. 2011, Witzel et al. 2013), as well as being associated with response to endocrine therapy and chemotherapy (Gonzalez-Angulo et al. 2009, Peters et al. 2009, Niemeier et al. 2010, Hu et al. 2011, Honma et al. 2012, Witzel et al. 2013). However, the prognosis of women with AR-positive breast cancer is exquisitely context dependent. When breast cancer is classified into molecular subgroups, AR expression is a consistent independent predictor of breast cancer survival only in the context of ER-positive disease (Luminal A and B subtypes) (Poulin et al. 1989, Birrell et al. 1998, Panet-Raymond et al. 2000, Peters et al. 2009, Castellano et al. 2010, Park et al. 2010, Hu et al. 2011). This reflects the anti-proliferative, anti-estrogenic influence of AR signalling in nearly all pre-clinical models of ER-positive breast cancer (Lanzino et al. 2005) and the powerful ability of androgens to suppress ER-mediated growth of the normal mammary epithelium (Peters et al. 2011).

The proposed use of androgens as a possible treatment for breast cancer dates as far back as 1939 (Ulrich 1939). Data regarding the inhibitory effect of androgens in pre-clinical models of breast cancer are supported by the clinical efficacy of androgen therapies such as methyl-testosterone and fluoxymesterone in the treatment of metastatic breast cancer, where disease regression was reported in up to 30\% of cases (Adair \& Herrmann 1946, Kennedy 1958, Goldenberg \& Hayes 1961, Goldenberg 1964, Manni et al. 1981).

\section{Role of AR in ER-negative breast cancer}

AR action critically depends on context, in particular whether ER is expressed or not. AR is an inconsistent biomarker of survival in the ER-negative context (Agoff et al. 2003, Doane et al. 2006, Peters et al. 2009, Hu et al. 2011) and AR exhibits a plasticity of action in models of ER-negative breast cancer in which both oncogenic and tumour suppressive effects have been reported, even in the same model (Hickey et al. 2012, Lim et al. 2014, Chia et al. 2015).

In a small proportion of ER-negative breast cancers known as molecular apocrine or luminal AR subtype, AR has been shown to genomically mimic the oncogenic actions of ER (Robinson et al. 2011). In breast cancer cell line models of molecular apocrine breast cancer, AR activates oncogenic Wnt and HER2 signalling via transcriptional induction of key proteins within those pathways (Ni et al. 2011). AR-associated oncogenic activity is dependent upon overexpression of the pioneer factor FOXA1 and altered interaction with other nuclear proteins. It has also been shown that different AR ligands exert opposing growth responses in the same ER-negative breast cancer cell line (Moore et al. 2012), potentially via ligand-specific differential recruitment of nuclear co-factors. It is important to note that the aforementioned studies rely heavily on a single cell line model of molecular apocrine breast cancer, namely MDA-MB-453, which has a mutation in the ligand-binding domain of AR that compromises receptor stability and potentially the response to androgenic ligands (Moore et al. 2012). This highlights a need to develop better models of apocrine breast cancer to fully understand the basis of AR-driven breast cancer growth in an ER-negative context. Currently there are several clinical trials investigating the efficacy of AR-directed therapies in cohorts of triple-negative breast cancer (TNBC, cancers that do not express ER, PR or HER2) (Gucalp et al. 2013, Traina et al. 2015). For the purposes of this review, we will concentrate on the role of AR and AR-directed therapy in ER-positive breast cancer.

\section{AR in ER-positive breast cancer}

In ER-positive breast cancer, the outcome of cross-talk between AR and ER appears to depend on their expression ratio. Although clinical and pre-clinical evidence overwhelmingly supports a tumour suppressive role for AR signalling in treatment-naïve ER-positive breast cancer, the MCF7 breast cancer cell line stands out as an exception, exhibiting AR-mediated proliferative effects dependent upon culture conditions. MCF7 cells typically overexpress ER and have low levels of AR, although this may depend on cell culture conditions resulting in fluctuations in AR activity. It has been shown that the AR antagonist enzalutamide inhibits estrogen-stimulated growth of MCF7 cells grown as tumour xenografts (Cochrane et al. 2014), in part by restricting AR nuclear uptake (D'Amato et al. 2016), whereas others have shown androgen-induced inhibition of ER-positive breast cancer cell proliferation (Birrell et al. 1995a). When ectopically overexpressed in MCF7 cells, AR exerts a robust anti-proliferative effect, in part due to altered interactions of ER and AR with a common transcriptional co-factor, ARA70 (Lanzino et al. 2005, Peters et al. 2009). In other ER-positive breast cancer cell lines (e.g. ZR75-1, T47D) that express AR and ER in more equal proportions, AR activation consistently inhibits proliferation (reviewed in Hickey et al. 2012). This also occurs in vivo, whereby androgen treatment delayed the onset of DMBA-induced rat mammary carcinomas

Published by Bioscientifica Ltd. 
(Zava \& McGuire 1977), whereas genetic ablation of AR hastened the onset of HER2- or DMBA-induced mouse mammary tumours in mice (Simanainen et al. 2012, Hodgson et al. 2013). Collectively, these data support the notion that the AR:ER ratio critically reflects the proliferative outcome of sex steroid hormone crosstalk in luminal breast cancers (Birrell et al. 2007).

In the setting of tamoxifen-resistant ER-positive breast cancer, there are conflicting studies with one study reporting that high AR conferred a survival advantage in a consecutive series of over 900 breast cancers (Castellano et al. 2010), and another in a cohort of 192 cases reporting the opposite (Cochrane et al. 2014). However, the latter study compared the relative outcome of a tamoxifen-resistant group dichotomised by level of AR expression rather than comparing tamoxifen-sensitive to resistant disease. In that study, a high AR:ER ratio was associated with resistance to tamoxifen, but a key determinant of the increase in the AR:ER ratio was a low ER, with $45 \%$ of cases studied having an ER positivity of $<20 \%$. AR has been shown to facilitate estrogen-independent ER activity in MCF7 cells that are resistant to anastrozole (Rechoum et al. 2014). A comparison of 21 patient-matched cases of primary and recurrent breast cancer (Fujii et al. 2014) showed a significant decrease in ER levels with no change in AR levels after the development of resistance to AI therapy, consistent with the ER and AR staining patterns in the aforementioned study by Cochrane and coworkers. AI-resistant derivatives of the ER-positive T47D breast cancer cell line have similarly been shown to maintain AR expression, but completely lose ER expression (Fujii et al. 2014). Collectively, these data suggest that alteration in the AR:ER expression ratio is a common feature of resistance to ER-directed therapy, but that this may be determined more by ER loss than
AR gain. Additional, larger studies in well-annotated populations are required to define the precise role of alterations in the AR:ER ratio with progression from endocrine-sensitive to resistant disease.

Two studies that compared tamoxifen to tamoxifen in combination with fluoxymesterone demonstrated improved clinical benefit with the combination in unselected breast cancer patients (Tormey et al. 1983, Ingle et al. 1991). In an exploratory analysis, patients aged older than 65 years with an ER level of $>10 \mathrm{fmol}$ had a significant improved survival from 7 to 18 months with the combination (Ingle et al. 1991). These studies provide clinical evidence that dual targeting of ER and AR may be of clinical benefit. Collectively, the pre-clinical and clinical evidence provide compelling support for a role of ligand-activated AR as a tumour suppressor in ER-positive breast cancer (Table 2).

Despite the therapeutic benefits seen with androgens, they fell from use as a class of agents due to virilising side effects, concerns regarding aromatization to estrogen, and the emergence of tamoxifen (Cole et al. 1971) and AIs (Coombes et al. 1984) as effective therapies in ER-positive breast cancer. Their initial use predated knowledge regarding AR expression and its potential role in ER-positive breast cancer. In light of recent new understanding of the interplay between SSRs in breast cancer, there has been a resurgence in interest in initiating innovative clinical trials to identify endocrine-based therapeutic strategies that enhance or are complementary to ER-directed interventions (Lonning 2009) (Table 3). These strategies are largely focused on targeting the AR signaling axis with antagonists of AR or inhibitors of androgen biosynthesis. It is intriguing that two opposing treatment strategies have been used in targeting AR in ER-positive breast cancer, namely an agonistic and an antagonistic strategy. The preclinical data supporting

Table 2 Studies of androgens and SARMs in metastatic breast cancer.

\begin{tabular}{|c|c|c|}
\hline Treatment & No. of patients & Median duration of response \\
\hline \multicolumn{3}{|l|}{ Androgen receptor agonists } \\
\hline Fluoxymesterone & 29 & 5.3 months \\
\hline $\begin{array}{l}\text { Fluoxymesterone vs TAM, } \\
\text { 1st line }\end{array}$ & 79 & - \\
\hline $\begin{array}{l}\text { Fluoxymesterone + TAM vs } \\
\text { TAM, 1st line }\end{array}$ & 238 & $\begin{array}{l}\text { FLU + TAM, } 11.6 \text { months; } \\
\text { TAM, } 6.5 \text { months }(P=0.03)\end{array}$ \\
\hline \multicolumn{3}{|c|}{ Selective androgen receptor modulators } \\
\hline Enobosarm, 2nd line & 17 & - \\
\hline
\end{tabular}

\section{Objective response and \\ clinical benefit rate}

CBR: $48 \%$

CBR: TAM, 30\%;

FLU, $19 \%$

ORR: FLU + TAM, 54\%;

TAM, $42 \%(P=0.07)$

CBR: $35 \%$
Reference

Kennedy (1957)

Westerberg (1980)

Ingle et al. (1991)

Overmoyer et al. (2015)

FLU, fluoxymesterone; CBR, clinical benefit rate; ORR, objective response rate.

Modulation of AR has not been studied as extensively as PR in the context of breast cancer. As with Table 1, a representative sample of studies accruing more than 20 participants is presented. 
Table 3 Current clinical trials investigating AR directed therapy strategies in breast cancer.

\begin{tabular}{|c|c|c|c|c|}
\hline Treatment & Other treatments & Phase & Cancer subtype & Clinicaltrials.gov identifier \\
\hline \multicolumn{5}{|c|}{ Androgen receptor antagonists } \\
\hline Enzalutamide & $\begin{array}{l}\text { Anastrozole, exemestane, } \\
\text { fulvestrant }\end{array}$ & I & Any/AR+ & NCT01597193 \\
\hline Enzalutamide & Exemestane & II & ER+ and/or PR+, HER2- & NCT02007512 \\
\hline Enzalutamide & Trastuzumab & II & $\mathrm{AR}+/ \mathrm{HER} 2+$ & NCT02091960 \\
\hline Enzalutamide & Exemestane & Window & $\mathrm{ER+}$ & NCT02676986 \\
\hline AZD5312 & - & II & AR+ solid tumours & NCT02144051 \\
\hline \multicolumn{5}{|c|}{ Selective androgen receptor modulators } \\
\hline Enobosarm & - & II & $\mathrm{ER}+, \mathrm{AR+}$ & NCT02463032 \\
\hline Enobosarm & - & Window & $\mathrm{ER}+, \mathrm{AR}+$ & EMERALD \\
\hline CR1447 & - & $\mathrm{I} / \mathrm{II}$ & $\begin{array}{l}\text { P I: ER+/HER2-P II: ER+/HER2- or } \\
\text { TNBC/AR+ }\end{array}$ & NCT02067741 \\
\hline \multicolumn{5}{|c|}{ Androgen biosynthesis inhibitors } \\
\hline VT-464 & - & $\mathrm{I} / \mathrm{II}$ & $\begin{array}{l}\text { P I: TNBC or ER+/HER2-P II: TNBC/AR+ } \\
\text { or ER+/HER2- }\end{array}$ & NCT02580448 \\
\hline Irosustat & $\begin{array}{l}\text { Aromatase inhibitor } \\
\text { (continued beyond progression) }\end{array}$ & II & $\mathrm{ER}+$ & NCT01785992 \\
\hline Irosustat & - & Window & $\mathrm{ER+}$ & NCT01662726 \\
\hline Orteronel & - & 1 & $\mathrm{ER}+$ & NCT01808040 \\
\hline Orteronel & - & II & TNBC/AR+; ER+ and/or PR+/AR+ & NCT01990209 \\
\hline \multicolumn{5}{|l|}{ Androgens } \\
\hline DHEA & Aromatase inhibitor & II & $\mathrm{ER}-/ \mathrm{PR}-/ \mathrm{AR}+$ or $\mathrm{ER}$ or $\mathrm{PR}+/ \mathrm{AR}+$ & NCT02000375 (terminated) \\
\hline
\end{tabular}

$A R$, androgen receptor; DHEA, dehydroepiandrosterone; ER, estrogen receptor; PR, progesterone receptor. Recruitment of advanced/metastatic breast cancer patients unless otherwise stated.

The majority of current clinical effort in this area is focussed on interventions affecting AR activity.

either of these two strategies in the context of ER-positive breast cancer is limited, but this has not deterred clinical trials to be conducted with both classes of drug, primarily in patients with endocrine-resistant metastatic breast cancer as summarized below.

\section{AR antagonists and androgen biosynthesis inhibitors in ER-positive breast cancer}

Enzalutamide is currently being evaluated in clinical trials of ER-positive breast cancer (Table 3). It acts by competitively inhibiting androgen binding, subsequent AR nuclear translocation and interaction with chromatin, and has been shown to bind to AR with greater relative affinity compared with other AR antagonists (Tran et al. 2009). In a phase I study, the pharmacokinetics and tolerability of enzalutamide in combination with AIs were similar to that reported in the initial trials of men with prostate cancer (Traina et al. 2014). As enzalutamide is an inducer of CYP3A4, it resulted in decreased circulating levels of AI and a corresponding increase in circulating estradiol levels in the study. Current clinical trials of enzalutamide in ER-positive breast cancer are summarized in Table 3. Finally, a phase I study (Clinicaltrials.gov identifier NCT02144051) to investigate the safety and pharmacokinetics of an antisense oligonucleotide AZD5312 (ISIS-ARRx), which targets AR mRNA, has just been completed in patients with advanced solid tumours, including breast cancer (Clinicaltrials.gov identifier NCT02144051).

Abiraterone acetate inhibits the hydroxylase CYP17, an enzyme involved in the biosynthesis of several steroidal hormones and hormone precursors, including ultimately androgens and estrogens. The FDA has approved its use in castrate-resistant prostate cancer. A randomized phase II study in postmenopausal patients with ER-positive metastatic breast cancer (O'Shaughnessy et al. 2016) reported no significant difference in progression-free survival with abiraterone compared with exemestane (3.7 vs 3.7 months; $\mathrm{HR}=1.1 ; P=0.437$ ) or for the combination of abiraterone plus exemestane compared with exemestane alone ( 4.5 vs 3.7 months; $\mathrm{HR}=0.96 ; P=0.794$ ). The reason for the lack of efficacy seen with abiraterone may be related to a reduction in testosterone or an increase in progesterone. Another CYP17 inhibitor, orteronel, has demonstrated promising results in pre-clinical studies (Kaku et al. 2011, Yamaoka et al. 2012, 2013).

In an alternative approach, irosustat (STX64), a first-generation irreversible inhibitor of steroid sulfatase (STS), has been shown to prevent the formation of androgenic steroids with estrogenic properties such as androstenedione $5 \alpha$-androstane- $3 \beta, 17 \beta$-diol, which have

Published by Bioscientifica Ltd 
been implicated in endocrine resistance (Sikora et al. 2009, 2012, Palmieri et al. 2011, O'Hara et al. 2012). Two phase I studies have demonstrated irosustat to be well tolerated and provided evidence of clinical activity (Stanway et al. 2006, Coombes et al. 2013).

\section{Selective AR modulators (SARMs)}

The rationale for using a SARM in the context of ER- and AR-positive breast cancer is based on preclinical studies that consistently demonstrate an anti-proliferative effect of AR agonists in this breast cancer subtype (reviewed in Hickey et al. 2012). Enobosarm (GTx-024) is a non-steroidal SARM, which binds and activates AR with an affinity, potency and efficacy similar to dihydrotestosterone (DHT) (Kim et al. 2005, Narayanan et al. 2008). Enobosarm has the advantage of having selective anabolic activity and lacking cutaneous androgenic activity. Additionally, enobosarm is not converted to estrogenic metabolites (Chen et al. 2005, Mohler et al. 2009, Coss et al. 2014).

A proof-of-concept phase II study in postmenopausal women with ER-positive metastatic breast cancer (Clinicaltrials.gov identifier NCT01616758) who had a mean of three prior lines of ER-directed therapies, demonstrated that enobosarm at a dose of $9 \mathrm{mg}$ daily has clinical activity (Overmoyer et al. 2015). Of the AR-positive patients, 35\% derived clinical benefit, with the six-month Kaplan-Meier estimate of progression free survival being 40.1\% (95\% CI: 18.1-62.1\%). Enobosarm has been shown to be safe and well tolerated in the context of a number of randomised phase II clinical studies (Dalton et al. 2011, Dobs et al. 2013). In the phase II metastatic breast cancer study, $95 \%$ of adverse events recorded were grade $1 / 2$, and included pain, fatigue, nausea, hot flashes/night sweats, arthralgia and anxiety (Overmoyer et al. 2015). A follow on phase II trial is currently recruiting patients with ER-positive metastatic breast cancer (Clinicaltrials.gov identifier NCT02463032). A randomised phase II pre-surgical window of opportunity study is also being undertaken to evaluate the effect of 2 weeks of enobosarm in untreated ER and AR-positive early breast cancer (EMERALD study, Cancer Research UK Grant number A20712). The primary endpoint in this study is change in Ki67 between baseline and end of treatment.

Another SARM currently being investigated is 4-hydroxytestosterone (CR1447), which strongly binds to AR and has aromatase-inhibiting activity (Ghosh et al. 2009). Pre-clinical studies demonstrated that 4-hydroxytestosterone has anti-proliferative activity in vitro in both ER-positive and TNBC cell lines and is dependent on the presence of the AR. Animal data have shown selective anabolic effects. In a phase I study, in patients with advanced breast cancer where 4-hydroxytestosterone was transdermally administered to avoid first-pass metabolism, it was well tolerated up to a dose of $400 \mathrm{mg}$ per day, with no dose-limiting toxicities noted (Schoenfeld et al. 2015). A phase II trial with 4-hydroxytestosterone at $400 \mathrm{mg}$ in metastatic, endocrine responsive/HER2-negative and AR-positive TNBC is currently underway (Clinicaltrials.gov identifier NCT02067741).

\section{Contemporary strategies for improving the treatment and outcomes for ER-positive breast cancer}

Biological insights acquired from new transcription factor mapping techniques such as Chromatin Immunoprecipitation followed by Sequencing (ChIPSeq) and Rapid Immunoprecipitation Mass spectrometry of Endogenous protein (RIME) (Hurtado et al. 2011, Ross-Innes et al. 2012, Mohammed et al. 2013, 2015) have highlighted the roles played by $\mathrm{PR}$ and $\mathrm{AR}$ in the regulation of ER signalling: opening new paths to tackling the most pressing needs in breast cancer therapy. It is becoming increasingly clear that substantial crosstalk occurs between SSRs, whereby the activation of one has a significant impact on the others. The mechanisms underlying receptor cross-talk have yet to be fully elucidated, but include competition for co-factors or consensus DNA-binding sites (Peters et al. 2009, Lim et al. 2012). More recently, it was demonstrated that activated PR reprograms ER chromatin binding, with many new ER-DNA interaction sites being detected within a short time after treatment with progesterone (Mohammed et al. 2015). This reprogramming of ER to novel cis-regulatory elements resulted in changes in gene expression profiles associated with cell cycle arrest, suggesting that activated PR was able to redirect ER chromatin binding and inhibit cell growth (Fig. 1). In support of this, progesterone inhibited estradiolinduced breast cancer cell proliferation as measured by Ki67 in patient-derived samples of primary breast cancer cultured ex-vivo. Moreover, treatment of MCF7 and T47D breast cancer xenografts with progesterone inhibited tumour growth, consistent with what has been reported in a patient-derived xenograft model of ER-positive and PR-positive breast cancer (Kabos et al. 2012). When combined with tamoxifen, the combination had greater

Published by Bioscientifica Ltd. 
Figure 1

Progesterone receptor (PR) reprograms estrogen receptor (ER) binding towards genes associated with good prognosis. In the absence of progesterone or the PR (left), ER binds to estrogen response elements and activates the expression of genes involved in cell proliferation and survival. In the presence of PR and progesterone (right), PR binds to and physically displaces the ER by binding to progesterone response elements at genes associated with cell differentiation and death. Therefore, progesterone is able to exert influence on the ER genomic binding landscape and expected to promote favourable outcomes in a subset of patients with ER- and PR-positive breast cancer. efficacy than either drug alone. Importantly, increased expression of a gene signature derived from progesteronestimulated ER chromatin binding (comprising 38 genes) conferred a good prognosis in the Metabric cohort of breast cancer patients ( $n=1957)$ (Curtis et al. 2012). This paper was seminal in that it challenged the previous common understanding of PR as a passive downstream marker of ER activity and identified a key role for PR in the regulation of ER function in breast cancer. These exciting new findings have the potential to open up a novel strategy to treat ER-positive breast cancer, specifically by modulating SSR crosstalk to reprogram ER signalling. Important considerations in translating these preclinical findings into clinical trials include knowing the SSRs that are co-expressed with ER, the type of SSR-directed drug used (i.e. antagonist or modulators, synthetic or natural), and whether the approach should be evaluated in endocrine-resistant or treatment-naive settings.

Although the traditional pathway for the majority of new therapies to be evaluated clinically begins in the metastatic context, pre-surgical clinical trials represent another validated strategy to evaluate novel therapies, particularly in ER-positive breast cancer, and can help to characterise the optimal target population (Dowsett et al. 2007, 2011, Goetz \& Suman 2016). The POETIC (perioperative aromatase inhibitor therapy followed by standard adjuvant therapy) (Clinicaltrials.gov identifier NCT02338310) and the ALTERNATE (fulvestrant and/ or anastrozole therapy in postmenopausal patients with stage II-III breast cancer undergoing surgery) (Clinicaltrials.gov identifier NCT01953588) trials are prospectively testing whether post-treatment Ki-67 levels can predict relapse-free survival. These trials will add to our understanding of whether the Ki-67 response is a valid biomarker strategy to identify patients with endocrine-sensitive disease. A valid criticism of Ki-67 as a predictive biomarker is the inter-laboratory and inter-observer variability, necessitating rigorous guidelines and quality assurance for clinical utility of this biomarker (Polley et al. 2013). A trial of a single depot injection of progesterone before surgery for ER-positive breast cancers in 976 patients demonstrated a significant improvement in survival outcomes in patients with higher risk node positive disease (Badwe et al. 2011). Window of opportunity studies to assess the effect of antiestrogen therapies, alone and in combination with micronized progesterone (prometrium) or a progestin (megestrol acetate) in patients with newly diagnosed ER and PR-positive breast cancer are currently being developed in Australia and UK. In the context of these trials, it is worth noting that although synthetic progestins have been associated with increased risk of developing breast cancer in the context of menopausal hormone therapy, in contrast, other studies have shown that hormone replacement therapies using native progesterone have resulted in no change or a slight decrease in breast cancer incidence (de Lignieres et al. 2002, Fournier et al. 2005, Espie et al. 2007, Fournier et al. 2008, Schneider et al. 2009).

\section{Concluding statements}

Emergent technologies are unravelling the extent and functional significance of SSR crosstalk in breast cancer, and ushering a new wave of clinical trials to understand how the potential breast cancer-suppressive effects of PR and AR can be harnessed in ER-positive breast cancer. Traditional approaches of studying the effects of individual hormones in isolation do not accurately reflect the interplay between different SSRs in breast cancer. Given that SSRs are structurally related, have similar consensus DNA-binding motifs and commonly use the same co-factors for activity, it is not surprising that there is substantial cross-talk between these receptors in breast

Published by Bioscientifica Ltd. 
cancer. Activation or inhibition of parallel hormonal pathways may therefore impact on the key receptor responsible for driving tumour growth.

The development of new generation AR antagonists in the context of prostate cancer has fast-tracked clinical trials focussed on inhibiting AR action in breast cancer, particularly in ER-negative breast cancer. Although it is still unclear if this is the correct strategy in ER-positive disease, where interaction of AR and ER signaling is complex and a critical consideration, clinical trials with AR antagonists have commenced in this setting. The emergence of SARMs, which act in opposing ways to AR antagonists, as a potential therapeutic strategy, highlights the lack of certainty regarding the best strategy and context to target AR. It is therefore critical that the SSR crosstalk be fully elucidated mechanistically in preclinical models that recapitulate the in vivo context to better inform the design of future clinical trials. The recent demonstration that progesterone stimulation of breast cancer cells in vitro and in vivo reprogrammed ER chromatin binding has identified a key role for PR in the regulation of ER-DNA interaction that has prognostic implications on patients with ER- and PR-positive breast cancer. This has led to a rethink of the role of PR, previously regarded solely as a downstream effector of ER, and a renewed interest in the development of PR-modulating strategies clinically. A key issue moving forward is if ER-directed therapies are required as a backbone for treatments that target $\mathrm{AR}$ and $\mathrm{PR}$, as is the case as in the case of combination strategies with mTOR and CDK 4/6 inhibitors. Of note, combination endocrine therapy has had mixed outcome. In the adjuvant setting, the combination of tamoxifen and anastrozole did not improve outcomes compared with tamoxifen alone (ATAC Group 2008). By contrast, in the metastatic setting, evidence does exist for combining anastrozole and fulvestrant (Mehta et al. 2012). Therefore, when considering potential combinatorial strategies, a rational approach based on either scientific data such the pre-clinical evidence for combining progesterone plus tamoxifen or the historical clinical data such as for fluoxymesterone and tamoxifen (Tormey et al. 1983, Ingle et al. 1991). Ultimately, any combination will need to be tested clinically and ideally in a window study as this is the most efficient mechanism for testing novel combination and will also allow the integration of targeted therapy.

The convergence of the necessary tools to study SSR crosstalk and next generation SSR modulators makes this an opportune time for new therapeutic strategies for pushing ER around in breast cancer.
Declaration of interest

$E L$ receives research funding support from Novartis. W D T and C P receives research funding support from GTx.

\section{Funding}

This work was supported by funding from the National Health and Medical Research Council of Australia (ID 1008349 and ID 1084416 to W D T and T E H), Cancer Australia/National Breast Cancer Foundation of Australia (ID 1043497 to W D T and T E H; ID 1107170 to E L, W D T and T E H), National Breast Cancer Foundation of Australia (PS-15-041 to W D T and G A T) and an unrestricted grant from GTX (W D T and TE H). TE H is a Career Development Fellow of the Royal Adelaide Hospital Research Foundation. E L is a National Breast Cancer Foundation Practitioner Fellow (PF14-02). $C P$ is supported by funding from Cancer Research UK and The Clatterbridge Cancer Charity.

Author contribution statement

All authors contributed to the writing of the review.

\section{References}

Abrams J, Aisner J, Cirrincione C, Berry DA, Muss HB, Cooper MR, Henderson IC, Panasci L, Kirshner J, Ellerton J, et al. 1999 Dose-response trial of megestrol acetate in advanced breast cancer: cancer and leukemia group B phase III study 8741. Journal of Clinical Oncology 17 64-73.

Adair FE \& Herrmann JB 1946 The use of testosterone propionate in the treatment of advanced carcinoma of the breast. Annals of Surgery $\mathbf{1 2 3}$ 1023-1035. (doi:10.1097/00000658-194606000-00006)

Agoff SN, Swanson PE, Linden H, Hawes SE \& Lawton TJ 2003 Androgen receptor expression in estrogen receptor-negative breast cancer. Immunohistochemical, clinical, and prognostic associations. American Journal of Clinical Pathology 120 725-731. (doi:10.1309/ 42F00D0DJD0J5EDT)

Andersen J, Kamby C, Ejlertsen B, Cold S, Ewertz M, Jacobsen EH, Philip P, Moller KA, Jensen D \& Moller S 2008 Tamoxifen for one year vs two years vs 6 months of Tamoxifen and 6 months of megestrol acetate: a randomized comparison in postmenopausal patients with high-risk breast cancer (DBCG 89C). Acta Oncologica 47 718-724. (doi:10.1080/02841860802014882)

ATAC Trialists' Group, Forbes JF, Cuzick J, Buzdar A, Howell A, Tobias JS \& Baum M 2008 Effect of anastrozole and tamoxifen as adjuvant treatment for early-stage breast cancer: 100-month analysis of the ATAC trial. Lancet Oncology 9 45-53. (doi:10.1016/S14702045(07)70385-6)

Bachelot T, Bourgier C, Cropet C, Ray-Coquard I, Ferrero JM, Freyer G, Abadie-Lacourtoisie S, Eymard JC, Debled M, Spaeth D, et al. 2012 Randomized phase II trial of everolimus in combination with tamoxifen in patients with hormone receptor-positive, human epidermal growth factor receptor 2-negative metastatic breast cancer with prior exposure to aromatase inhibitors: a GINECO study. Journal of Clinical Oncology 30 2718-2724. (doi:10.1200/ JCO.2011.39.0708)

Badwe R, Hawaldar R, Parmar V, Nadkarni M, Shet T, Desai S, Gupta S, Jalali R, Vanmali V, Dikshit R, et al. 2011 Single-injection depot progesterone before surgery and survival in women with operable breast cancer: a randomized controlled trial. Journal of Clinical Oncology 29 2845-2851. (doi:10.1200/JCO.2010.33.0738)

Bardou VJ, Arpino G, Elledge RM, Osborne CK \& Clark GM 2003 Progesterone receptor status significantly improves outcome prediction over estrogen receptor status alone for adjuvant endocrine

Published by Bioscientifica Ltc 
therapy in two large breast cancer databases. Journal of Clinical Oncology 21 1973-1979. (doi:10.1200/JCO.2003.09.099)

Baselga J, Campone M, Piccart M, Burris HA 3rd, Rugo HS, Sahmoud T, Noguchi S, Gnant M, Pritchard KI, Lebrun F, et al. 2012 Everolimus in postmenopausal hormone-receptor-positive advanced breast cancer. New England Journal of Medicine 366 520-529. (doi:10.1056/ NEJMoa1109653)

Baselga J, Im S-A, Iwata H, Clemons M, Ito Y, Awada A, Chia S, Jagiello-Gruszfeld A, Pistilli B, Tseng L-M, et al. 2016 PIK3CA status in circulating tumor DNA (ctDNA) predicts efficacy of buparlisib (BUP) plus fulvestrant (FULV) in postmenopausal women with endocrine-resistant HR+/HER2- advanced breast cancer (BC): first results from the randomized, phase III BELLE-2 tria. Cancer Research 76 (Supplement) Ab S6-01. (doi:10.1158/1538-7445.AM2016-6)

Bines J, Dienstmann R, Obadia RM, Branco LG, Quintella DC, Castro TM, Camacho PG, Soares FA \& Costa ME 2014 Activity of megestrol acetate in postmenopausal women with advanced breast cancer after nonsteroidal aromatase inhibitor failure: a phase II trial. Annals of Oncology 25 831-836. (doi:10.1093/annonc/mdu015)

Birrell SN, Bentel JM, Hickey TE, Ricciardelli C, Weger MA, Horsfall DJ \& Tilley WD 1995a Androgens induce divergent proliferative responses in human breast cancer cell lines. Journal of Steroid Biochemistry and Molecular Biology 52 459-467. (doi:10.1016/09600760(95)00005-K)

Birrell SN, Roder DM, Horsfall DJ, Bentel JM \& Tilley WD 1995b Medroxyprogesterone acetate therapy in advanced breast cancer: the predictive value of androgen receptor expression. Journal of Clinical Oncology 13 1572-1577.

Birrell SN, Hall RE \& Tilley WD 1998 Role of the androgen receptor in human breast cancer. Journal of Mammary Gland Biology and Neoplasia 3 95-103. (doi:10.1023/A:1018730519839)

Birrell SN, Butler LM, Harris JM, Buchanan G \& Tilley WD 2007 Disruption of androgen receptor signaling by synthetic progestins may increase risk of developing breast cancer. FASEB Journal $\mathbf{2 1}$ 2285-2293. (doi:10.1096/fj.06-7518com)

Brufman G, Isacson R, Haim N, Gez E \& Sulkes A 1994 Megestrol acetate in advanced breast carcinoma after failure to tamoxifen and/or aminoglutethimide. Oncology 51 258-261. (doi:10.1159/000227345)

Cancer Genome Atlas Network 2012 Comprehensive molecular portraits of human breast tumours. Nature 490 61-70. (doi:10.1038/ nature11412)

Canney PA, Priestman TJ, Griffiths T, Latief TN, Mould JJ \& Spooner D 1988 Randomized trial comparing aminoglutethimide with high-dose medroxyprogesterone acetate in therapy for advanced breast carcinoma. Journal of the National Cancer Institute $\mathbf{8 0}$ 1147-1151. (doi:10.1093/jnci/80.14.1147)

Castellano I, Allia E, Accortanzo V, Vandone AM, Chiusa L, Arisio R, Durando A, Donadio M, Bussolati G, Coates AS, et al. 2010 Androgen receptor expression is a significant prognostic factor in estrogen receptor positive breast cancers. Breast Cancer Research and Treatment 124 607-617. (doi:10.1007/s10549-010-0761-y)

Chandarlapaty S, Chen D, He W, Sung P, Samoila A, You D, Bhatt T, Patel P, Voi M, Gnant M, et al. 2016 Prevalence of ESR1 mutations in cell-free DNA and outcomes in metastatic breast cancer: a secondary analysis of the BOLERO-2 clinical trial. JAMA Oncology 2 1310-1315. (doi:10.1001/jamaoncol.2016.1279)

Chen J, Kim J \& Dalton JT 2005 Discovery and therapeutic promise of selective androgen receptor modulators. Molecular Interventions $\mathbf{5}$ 173-188. (doi:10.1124/mi.5.3.7)

Chia K, O’Brien M, Brown M \& Lim E 2015 Targeting the androgen receptor in breast cancer. Current Oncology Reports 17427. (doi:10.1016/j.currproblcancer.2016.09.004)

Cimino-Mathews A, Hicks JL, Illei PB, Halushka MK, Fetting JH, De Marzo AM, Park BH \& Argani P 2012 Androgen receptor expression is usually maintained in initial surgically resected breast cancer metastases but is often lost in end-stage metastases found at autopsy. Human Pathology 43 1003-1011. (doi:10.1016/j.humpath. 2011.08.007)

Cochrane DR, Bernales S, Jacobsen BM, Cittelly DM, Howe EN, D'Amato NC, Spoelstra NS, Edgerton SM, Jean A, Guerrero J, et al. 2014 Role of the androgen receptor in breast cancer and preclinical analysis of enzalutamide. Breast Cancer Research 16 R7. (doi:10.1186/ bcr3599)

Cole MP, Jones CT \& Todd ID 1971 A new anti-oestrogenic agent in late breast cancer. An early clinical appraisal of ICI46474. British Journal of Cancer 25 270-275. (doi:10.1038/bjc.1971.33)

Collins LC, Cole KS, Marotti JD, Hu R, Schnitt SJ \& Tamimi RM 2011 Androgen receptor expression in breast cancer in relation to molecular phenotype: results from the Nurses' Health Study. Modern Pathology 24 924-931. (doi:10.1038/modpathol.2011.54)

Coombes RC, Goss P, Dowsett M, Gazet JC \& Brodie A 1984 4-Hydroxyandrostenedione in treatment of postmenopausal patients with advanced breast cancer. Lancet 2 1237-1239. (doi:10.1016/ S0140-6736(84)92795-8)

Coombes RC, Cardoso F, Isambert N, Lesimple T, Soulie P, Peraire C, Fohanno V, Kornowski A, Ali T \& Schmid P 2013 A phase I dose escalation study to determine the optimal biological dose of irosustat, an oral steroid sulfatase inhibitor, in postmenopausal women with estrogen receptor-positive breast cancer. Breast Cancer Research and Treatment 140 73-82. (doi:10.1007/s10549-013-2597-8)

Coss CC, Jones A \& Dalton JT 2014 Selective androgen receptor modulators as improved androgen therapy for advanced breast cancer. Steroids 90 94-100. (doi:10.1016/j.steroids.2014.06.010)

Curtis C, Shah SP, Chin SF, Turashvili G, Rueda OM, Dunning MJ, Speed D, Lynch AG, Samarajiwa S, Yuan Y, et al. 2012 The genomic and transcriptomic architecture of 2000 breast tumours reveals novel subgroups. Nature 486 346-352. (doi:10.1038/nature10983)

Cuzick J, Dowsett M, Pineda S, Wale C, Salter J, Quinn E, Zabaglo L, Mallon E, Green AR, Ellis IO, et al. 2011 Prognostic value of a combined estrogen receptor, progesterone receptor, Ki-67, and human epidermal growth factor receptor 2 immunohistochemical score and comparison with the Genomic Health recurrence score in early breast cancer. Journal of Clinical Oncology 29 4273-4278. (doi:10.1200/JCO.2010.31.2835)

D'Amato NC, Gordon MA, Babbs B, Spoelstra NS, Carson Butterfield KT, Torkko KC, Phan VT, Barton VN, Rogers TJ, Sartorius CA, et al. 2016 Cooperative dynamics of AR and ER activity in breast cancer. Molecular Cancer Research [in press]. (doi:10.1158/1541-7786.MCR-160167)

Dalton JT, Barnette KG, Bohl CE, Hancock ML, Rodriguez D, Dodson ST, Morton RA \& Steiner MS 2011 The selective androgen receptor modulator GTx-024 (enobosarm) improves lean body mass and physical function in healthy elderly men and postmenopausal women: results of a double-blind, placebo-controlled phase II trial. Journal of Cachexia, Sarcopenia and Muscle 2 153-161. (doi:10.1007/ s13539-011-0034-6)

de Lignieres B, de Vathaire F, Fournier S, Urbinelli R, Allaert F, Le MG \& Kuttenn F 2002 Combined hormone replacement therapy and risk of breast cancer in a French cohort study of 3175 women. Climacteric 5 332-340. (doi:10.1080/cmt.5.4.332.340)

Doane AS, Danso M, Lal P, Donaton M, Zhang L, Hudis C \& Gerald WL 2006 An estrogen receptor-negative breast cancer subset characterized by a hormonally regulated transcriptional program and response to androgen. Oncogene 25 3994-4008. (doi:10.1038/ sj.onc.1209415)

Dobs AS, Boccia RV, Croot CC, Gabrail NY, Dalton JT, Hancock ML, Johnston MA \& Steiner MS 2013 Effects of enobosarm on muscle wasting and physical function in patients with cancer: a double-blind, randomised controlled phase 2 trial. Lancet Oncology 14 335-345. (doi:10.1016/S1470-2045(13)70055-X)

Dowsett M, Smith IE, Ebbs SR, Dixon JM, Skene A, A'Hern R, Salter J, Detre S, Hills M, Walsh G, et al. 2007 Prognostic value of Ki67 
expression after short-term presurgical endocrine therapy for primary breast cancer. Journal of the National Cancer Institute 99 167-170. (doi:10.1093/jnci/djk020)

Dowsett M, Cuzick J, Ingle J, Coates A, Forbes J, Bliss J, Buyse M, Baum M, Buzdar A, Colleoni M, et al. 2010 Meta-analysis of breast cancer outcomes in adjuvant trials of aromatase inhibitors vs tamoxifen. Journal of Clinical Oncology 28 509-518. (doi:10.1200/ JCO.2009.23.1274)

Dowsett M, Smith I, Robertson J, Robison L, Pinhel I, Johnson L, Salter J, Dunbier A, Anderson H, Ghazoui Z, et al. 2011 Endocrine therapy, new biologicals, and new study designs for presurgical studies in breast cancer. Journal of the National Cancer Institute Monographs 2011 120-123. (doi:10.1093/jncimonographs/lgr034)

Early Breast Cancer Trialists' Collaborative Group, Davies C, Godwin J, Gray R, Clarke M, Cutter D, Darby S, McGale P, Pan HC, Taylor C, et al. 2011 Relevance of breast cancer hormone receptors and other factors to the efficacy of adjuvant tamoxifen: patient-level meta-analysis of randomised trials. Lancet 378 771-784. (doi:10.1016/S0140-6736(11)60993-8)

Early Breast Cancer Trialists' Collaborative Group, Dowsett M, Forbes JF, Bradley R, Ingle J, Aihara T, Bliss J, Boccardo F, Coates A, Coombes RC, et al. 2015 Aromatase inhibitors vs tamoxifen in early breast cancer: patient-level meta-analysis of the randomised trials. Lancet 386 1341-1352. (doi:10.1016/S0140-6736(15)61074-1)

Ellis MJ, Ding L, Shen D, Luo J, Suman VJ, Wallis JW, Van Tine BA, Hoog J, Goiffon RJ, Goldstein TC, et al. 2012 Whole-genome analysis informs breast cancer response to aromatase inhibition. Nature $\mathbf{4 8 6}$ 353-360. (doi:10.1038/nature11143)

Espie M, Daures JP, Chevallier T, Mares P, Micheletti MC \& De Reilhac P 2007 Breast cancer incidence and hormone replacement therapy: results from the MISSION study, prospective phase. Gynecological Endocrinology 23 391-397. (doi:10.1080/09513590701382104)

Ettinger DS, Allegra J, Bertino JR, Bonomi P, Browder H, Byrne P, Carpenter J, Catalano R, Creech R, Dana B, et al. 1986 Megestrol acetate $\mathrm{v}$ tamoxifen in advanced breast cancer: correlation of hormone receptors and response. Seminars in Oncology 13 (Supplement 4) 9-14.

Finn RS, Crown JP, Lang I, Boer K, Bondarenko IM, Kulyk SO, Ettl J, Patel R, Pinter T, Schmidt M, et al. 2015 The cyclin-dependent kinase $4 / 6$ inhibitor palbociclib in combination with letrozole vs letrozole alone as first-line treatment of oestrogen receptor-positive, HER2-negative, advanced breast cancer (PALOMA-1/TRIO-18): a randomised phase 2 study. Lancet Oncology 16 25-35. (doi:10.1016/ S1470-2045(14)71159-3)

Finn RS, Martin M, Rugo HS, Jones SE, Im S, Gelmon KA, Harbeck N, Lipatov ON, Walshe JM, Moulder SL, et al. 2016 PALOMA-2: primary results from a phase III trial of palbociclib (P) with letrozole (L) compared with letrozole alone in postmenopausal women with ER+/HER2- advanced breast cancer (ABC). Journal of Clinical Oncology 34 (Supplement) Ab 507.

Fisher B, Redmond C, Fisher ER \& Caplan R 1988 Relative worth of estrogen or progesterone receptor and pathologic characteristics of differentiation as indicators of prognosis in node negative breast cancer patients: findings from National Surgical Adjuvant Breast and Bowel Project Protocol B-06. Journal of Clinical Oncology 6 1076-1087.

Fournier A, Berrino F, Riboli E, Avenel V \& Clavel-Chapelon F 2005 Breast cancer risk in relation to different types of hormone replacement therapy in the E3N-EPIC cohort. International Journal of Cancer 114 448-454. (doi:10.1002/ijc.20710)

Fournier A, Berrino F \& Clavel-Chapelon F 2008 Unequal risks for breast cancer associated with different hormone replacement therapies: results from the E3N cohort study. Breast Cancer Research and Treatment 107 103-111. (doi:10.1007/s10549-007-9523-x)

Fribbens C, O'Leary B, Kilburn L, Hrebien S, Garcia-Murillas I, Beaney M, Cristofanilli M, Andre F, Loi S, Loibl S, et al. 2016 Plasma
ESR1 mutations and the treatment of estrogen receptor-positive advanced breast cancer. Journal of Clinical Oncology 34 2961-2968. (doi:10.1200/JCO.2016.67.3061)

Fujii R, Hanamura T, Suzuki T, Gohno T, Shibahara Y, Niwa T, Yamaguchi Y, Ohnuki K, Kakugawa Y, Hirakawa H, et al. 2014 Increased androgen receptor activity and cell proliferation in aromatase inhibitor-resistant breast carcinoma. Journal of Steroid Biochemistry and Molecular Biology 144 513-522. (doi:10.1016/ j.jsbmb.2014.08.019)

Fuqua SA, Gu G \& Rechoum Y 2014 Estrogen receptor (ER) alpha mutations in breast cancer: hidden in plain sight. Breast Cancer Research and Treatment 144 11-19. (doi:10.1007/s10549-014-2847-4)

Germain P, Staels B, Dacquet C, Spedding M \& Laudet V 2006 Overview of nomenclature of nuclear receptors. Pharmacological Reviews $\mathbf{5 8}$ 685-704. (doi:10.1124/pr.58.4.2)

Ghosh D, Griswold J, Erman M \& Pangborn W 2009 Structural basis for androgen specificity and oestrogen synthesis in human aromatase. Nature 457 219-223. (doi:10.1038/nature07614)

Goetz MP \& Suman VJ 2016 Window-of-opportunity trials in the preoperative setting: insights into drug development for estrogen receptor-positive breast cancer. Journal of Clinical Oncology $\mathbf{3 4}$ 1970-1972. (doi:10.1200/JCO.2015.66.2312)

Goldenberg IS 1964 Testosterone propionate therapy in breast cancer. JAMA 188 1069-1072. (doi:10.1001/jama.1964.03060380037009)

Goldenberg IS \& Hayes MA 1961 Hormonal therapy of metastatic female breast carcinoma. II. 2alpha-Methyl dihydrotestosterone propionate. Cancer 14 705-706. (doi:10.1002/10970142(199007/08)14:4<705::AID-CNCR2820140405>3.0.CO;2-I)

Gonzalez-Angulo AM, Stemke-Hale K, Palla SL, Carey M, Agarwal R, Meric-Berstam F, Traina TA, Hudis C, Hortobagyi GN, Gerald WL, et al. 2009 Androgen receptor levels and association with PIK3CA mutations and prognosis in breast cancer. Clinical Cancer Research 15 2472-2478. (doi:10.1158/1078-0432.CCR-08-1763)

Gucalp A, Tolaney S, Isakoff SJ, Ingle JN, Liu MC, Carey LA, Blackwell K, Rugo H, Nabell L, Forero A, et al. 2013 Phase II trial of bicalutamide in patients with androgen receptor-positive, estrogen receptor-negative metastatic breast cancer. Clinical Cancer Research 19 5505-5512. (doi:10.1158/1078-0432.CCR-12-3327)

Hickey TE, Robinson JL, Carroll JS \& Tilley WD 2012 Minireview: the androgen receptor in breast tissues: growth inhibitor, tumor suppressor, oncogene? Molecular Endocrinology 26 1252-1267. (doi:10.1210/me.2012-1107)

Hodgson MC, Vanostran G, Alghamdi S, Poppiti RJ, Agoulnik AI \& Agoulnik IU 2013 Reduced androgen receptor expression accelerates the onset of ERBB2 induced breast tumors in female mice. PLOS ONE 8 e60455. (doi:10.1371/journal.pone.0060455)

Honma N, Horii R, Iwase T, Saji S, Younes M, Ito Y \& Akiyama F 2012 Clinical importance of androgen receptor in breast cancer patients treated with adjuvant tamoxifen monotherapy. Breast Cancer 20 323-330. (doi:10.1007/s12282-012-0337-2)

Hu R, Dawood S, Holmes MD, Collins LC, Schnitt SJ, Cole K, Marotti JD, Hankinson SE, Colditz GA \& Tamimi RM 2011 Androgen receptor expression and breast cancer survival in postmenopausal women. Clinical Cancer Research 17 1867-1874. (doi:10.1158/ 1078-0432.CCR-10-2021)

Hurtado A, Holmes KA, Ross-Innes CS, Schmidt D \& Carroll JS 2011 FOXA1 is a key determinant of estrogen receptor function and endocrine response. Nature Genetics 43 27-33. (doi:10.1038/ng.730)

Ingle JN, Ahmann DL, Green SJ, Edmonson JH, Creagan ET, Hahn RG \& Rubin J 1982 Randomized clinical trial of megestrol acetate vs tamoxifen in paramenopausal or castrated women with advanced breast cancer. American Journal of Clinical Oncology 5 155-160. (doi:10.1097/00000421-198204000-00062)

Ingle JN, Twito DI, Schaid DJ, Cullinan SA, Krook JE, Mailliard JA, Tschetter LK, Long HJ, Gerstner JG, Windschitl HE, et al. 1991 Combination hormonal therapy with tamoxifen plus http://erc.endocrinology-journals.org

DOI: 10.1530/ERC-16-0427
(C) 2016 Society for Endocrinology Printed in Great Britain 
fluoxymesterone vs tamoxifen alone in postmenopausal women with metastatic breast cancer. An updated analysis. Cancer 67 886-891. (doi:10.1002/1097-0142(19910215)67:4<886::AIDCNCR2820670405>3.0.CO;2-O)

Jeselsohn R, Buchwalter G, De Angelis C, Brown M \& Schiff R 2015 ESR1 mutations-a mechanism for acquired endocrine resistance in breast cancer. Nature Reviews Clinical Oncology 12 573-583. (doi:10.1038/nrclinonc.2015.117)

Jonat W, Bachelot T, Ruhstaller T, Kuss I, Reimann U \& Robertson JF 2013 Randomized phase II study of lonaprisan as second-line therapy for progesterone receptor-positive breast cancer. Annals of Oncology 24 2543-2548. (doi:10.1093/annonc/mdt216)

Kabos P, Finlay-Schultz J, Li C, Kline E, Finlayson C, Wisell J, Manuel CA, Edgerton SM, Harrell JC, Elias A, et al. 2012 Patient-derived luminal breast cancer xenografts retain hormone receptor heterogeneity and help define unique estrogen-dependent gene signatures. Breast Cancer Research and Treatment 135 415-432. (doi:10.1007/s10549-012-2164-8)

Kaku T, Hitaka T, Ojida A, Matsunaga N, Adachi M, Tanaka T, Hara T, Yamaoka M, Kusaka M, Okuda T, et al. 2011 Discovery of orteronel (TAK-700), a naphthylmethylimidazole derivative, as a highly selective 17,20-lyase inhibitor with potential utility in the treatment of prostate cancer. Bioorganic and Medicinal Chemistry 19 6383-6399. (doi:10.1016/j.bmc.2011.08.066)

Kennedy BJ 1957 Fluoxymesterone in the treatment of advanced breast cancer. Cancer 10 813-818.

Kennedy BJ 1958 Fluoxymesterone therapy in advanced breast cancer. New England Journal of Medicine 259 673-675. (doi:10.1056/ NEJM195810022591404)

Kim J, Wu D, Hwang DJ, Miller DD \& Dalton JT 2005 The para substituent of S-3-(phenoxy)-2-hydroxy-2-methyl-N-(4-nitro-3trifluoromethyl-phenyl)-propionamides is a major structural determinant of in vivo disposition and activity of selective androgen receptor modulators. Journal of Pharmacology and Experimental Therapeutics $\mathbf{3 1 5}$ 230-239. (doi:10.1124/ jpet.105.088344)

Klijn JG, de Jong FH, Bakker GH, Lamberts SW, Rodenburg CJ \& Alexieva-Figusch J 1989 Antiprogestins, a new form of endocrine therapy for human breast cancer. Cancer Research $492851-2856$.

Koornstra RH, Beelen KJ, Vincent AD, van der Noort V, van Diest PJ \& Linn SC 2015 St Gallen endocrine response classes predict recurrence rates over time. Breast 24 705-712. (doi:10.1016/j. breast.2015.08.009)

Krop IE, Mayer IA, Ganju V, Dickler M, Johnston S, Morales S, Yardley DA, Melichar B, Forero-Torres A, Lee SC, et al. 2016 Pictilisib for oestrogen receptor-positive, aromatase inhibitor-resistant, advanced or metastatic breast cancer (FERGI): a randomised, double-blind, placebo-controlled, phase 2 trial. Lancet Oncology 17 811-821. (doi:10.1016/S1470-2045(16)00106-6)

Lanzino M, De Amicis F, McPhaul MJ, Marsico S, Panno ML \& Ando S 2005 Endogenous coactivator ARA70 interacts with estrogen receptor alpha (ERalpha) and modulates the functional ERalpha/androgen receptor interplay in MCF-7 cells. Journal of Biological Chemistry 280 20421-20430. (doi:10.1074/jbc.M413576200)

Lea OA, Kvinnsland S \& Thorsen T 1989 Improved measurement of androgen receptors in human breast cancer. Cancer Research 49 (Part 1) 7162-7167.

Lim E, Ni M, Hazra A, Tamini R \& Brown M 2012 Elucidating the role of androgen receptors in breast cancer. Clinical Investigation 2 1003-1011. (doi:10.4155/cli.12.88)

Lim E, Ni M, Cao S, Hazra A, Tamimi RM \& Brown M 2014 Importance of breast cancer subtype in the development of androgen receptor directed therapy. Current Breast Cancer Reports 6 71-78. (doi:10.1007/ s12609-014-0140-5)

Loibl S, Muller BM, von Minckwitz G, Schwabe M, Roller M, Darb-Esfahani S, Ataseven B, du Bois A, Fissler-Eckhoff A, Gerber B,

http://erc.endocrinology-journals.org DOI: 10.1530/ERC-16-0427
○ 2016 Society for Endocrinology Printed in Great Britain et al. 2011 Androgen receptor expression in primary breast cancer and its predictive and prognostic value in patients treated with neoadjuvant chemotherapy. Breast Cancer Research and Treatment 130 477-487. (doi:10.1007/s10549-011-1715-8)

Lonning PE 2000 Clinico-pharmacological aspects of different hormone treatments. European Journal of Cancer 36 (Supplement 4) S81-S82. (doi:10.1016/S0959-8049(00)00237-9)

Lonning PE 2009 Additive endocrine therapy for advanced breast cancer - back to the future. Acta Oncologica 48 1092-1101. (doi:10.3109/02841860903117816)

Lundgren S, Gundersen S, Klepp R, Lonning PE, Lund E \& Kvinnsland S 1989 Megestrol acetate vs aminoglutethimide for metastatic breast cancer. Breast Cancer Research and Treatment 14 201-206. (doi:10.1007/BF01810736)

Manni A, Arafah BM \& Pearson OH 1981 Androgen-induced remissions after antiestrogen and hypophysectomy in stage IV breast cancer. Cancer 48 2507-2509. (doi:10.1002/10970142(19811201)48:11<2507::AID-CNCR2820481127>3.0.CO;2-E)

Martoni A, Longhi A, Canova N \& Pannuti F 1991 High-dose medroxyprogesterone acetate vs oophorectomy as first-line therapy of advanced breast cancer in premenopausal patients. Oncology $\mathbf{4 8}$ 1-6. (doi:10.1159/000226884)

McNamara KM, Moore NL, Hickey TE, Sasano H \& Tilley WD 2014 Complexities of androgen receptor signalling in breast cancer. Endocrine-Related Cancer 21 T161-T181. (doi:10.1530/ERC-14-0243)

McNamara KM \& Sasano H 2015 The intracrinology of breast cancer. Journal of Steroid Biochemistry and Molecular Biology 145 172-178. (doi:10.1016/j.jsbmb.2014.04.004)

Mehta RS, Barlow WE, Albain KS, Vandenberg TA, Dakhil SR, Tirumali NR, Lew DL, Hayes DF, Gralow JR, Livingston RB, et al. 2012 Combination anastrozole and fulvestrant in metastatic breast cancer. New England Journal of Medicine 367 435-444. (doi:10.1056/ NEJMoa1201622)

Micello D, Marando A, Sahnane N, Riva C, Capella C \& Sessa F 2010 Androgen receptor is frequently expressed in HER2-positive, ER/ PR-negative breast cancers. Virchows Archiv 457 467-476. (doi:10.1007/s00428-010-0964-y)

Mohammed H, D'Santos C, Serandour AA, Ali HR, Brown GD, Atkins A, Rueda OM, Holmes KA, Theodorou V, Robinson JL, et al. 2013 Endogenous purification reveals GREB1 as a key estrogen receptor regulatory factor. Cell Reports 3 342-349. (doi:10.1016/j. celrep.2013.01.010)

Mohammed H, Russell IA, Stark R, Rueda OM, Hickey TE, Tarulli GA, Serandour AA, Birrell SN, Bruna A, Saadi A, et al. 2015 Progesterone receptor modulates ERalpha action in breast cancer. Nature $\mathbf{5 2 3}$ 313-317. (doi:10.1038/nature14583)

Mohler ML, Bohl CE, Jones A, Coss CC, Narayanan R, He Y, Hwang DJ, Dalton JT \& Miller DD 2009 Nonsteroidal selective androgen receptor modulators (SARMs): dissociating the anabolic and androgenic activities of the androgen receptor for therapeutic benefit. Journal of Medicinal Chemistry 52 3597-3617. (doi:10.1021/ jm900280m)

Moinfar F, Okcu M, Tsybrovskyy O, Regitnig P, Lax SF, Weybora W, Ratschek M, Tavassoli FA \& Denk H 2003 Androgen receptors frequently are expressed in breast carcinomas: potential relevance to new therapeutic strategies. Cancer 98 703-711. (doi:10.1002/ cncr.11532)

Moore NL, Buchanan G, Harris JM, Selth LA, Bianco-Miotto T, Hanson AR, Birrell SN, Butler LM, Hickey TE \& Tilley WD 2012 An androgen receptor mutation in the MDA-MB-453 cell line model of molecular apocrine breast cancer compromises receptor activity. Endocrine-Related Cancer 19 599-613. (doi:10.1530/ERC12-0065)

Muss HB, Wells HB, Paschold EH, Black WR, Cooper MR, Capizzi RL, Christian R, Cruz JM, Jackson DV, Powell BL, et al. 1988 Megestrol acetate vs tamoxifen in advanced breast cancer: 5-year analysis - a 
phase III trial of the Piedmont Oncology Association. Journal of Clinical Oncology 6 1098-1106.

Muss HB, Case LD, Capizzi RL, Cooper MR, Cruz J, Jackson D, Richards F 2nd, Powell BL, Spurr CL, White D, et al. 1990 Highversus standard-dose megestrol acetate in women with advanced breast cancer: a phase III trial of the Piedmont Oncology Association. Journal of Clinical Oncology 8 1797-1805.

Muss HB, Case LD, Atkins JN, Bearden JD 3rd, Cooper MR, Cruz JM, Jackson DV Jr, O'Rourke MA, Pavy MD, Powell BL, et al. 1994 Tamoxifen vs high-dose oral medroxyprogesterone acetate as initial endocrine therapy for patients with metastatic breast cancer: a Piedmont Oncology Association study. Journal of Clinical Oncology 12 1630-1638.

Nadji M, Gomez-Fernandez C, Ganjei-Azar P \& Morales AR 2005 Immunohistochemistry of estrogen and progesterone receptors reconsidered: experience with 5993 breast cancers. American Journal of Clinical Pathology 123 21-27. (doi:10.1309/4WV79N2GHJ3X1841)

Narayanan R, Coss CC, Yepuru M, Kearbey JD, Miller DD \& Dalton JT 2008 Steroidal androgens and nonsteroidal, tissue-selective androgen receptor modulator, S-22, regulate androgen receptor function through distinct genomic and nongenomic signaling pathways. Molecular Endocrinology 22 2448-2465. (doi:10.1210/me.2008-0160)

Ni M, Chen Y, Lim E, Wimberly H, Bailey ST, Imai Y, Rimm DL, Liu XS \& Brown M 2011 Targeting androgen receptor in estrogen receptor-negative breast cancer. Cancer Cells 20 119-131. (doi:10.1016/j.ccr.2011.05.026)

Nicolas Diaz-Chico B, German Rodriguez F, Gonzalez A, Ramirez R, Bilbao C, Cabrera de Leon A, Aguirre Jaime A, Chirino R, Navarro D \& Diaz-Chico JC 2007 Androgens and androgen receptors in breast cancer. Journal of Steroid Biochemistry and Molecular Biology 105 1-15. (doi:10.1016/j.jsbmb.2006.11.019)

Niemeier LA, Dabbs DJ, Beriwal S, Striebel JM \& Bhargava R 2010 Androgen receptor in breast cancer: expression in estrogen receptor-positive tumors and in estrogen receptor-negative tumors with apocrine differentiation. Modern Pathology 23 205-212. (doi:10.1038/modpathol.2009.159)

O'Hara J, Vareslija D, McBryan J, Bane F, Tibbitts P, Byrne C, Conroy RM, Hao Y, Gaora PO, Hill AD, et al. 2012 AIB1:ERalpha transcriptional activity is selectively enhanced in aromatase inhibitor-resistant breast cancer cells. Clinical Cancer Research 18 3305-3315. (doi:10.1158/1078-0432.ccr-11-3300)

O'Shaughnessy J, Campone M, Brain E, Neven P, Hayes D, Bondarenko I, Griffin TW, Martin J, De Porre P, Kheoh T, et al. 2016 Abiraterone acetate, exemestane or the combination in postmenopausal patients with estrogen receptor-positive metastatic breast cancerdagger. Annals of Oncology 27 106-113. (doi:10.1093/ annonc/mdv487)

Overmoyer B, Sanz-Altimira P, Partridge AH, Extermann M, Liu J, Winer E, Lin N, Hassett M, Parker L, Taylor R, et al. 2015 Enobosarm for the treatment of metastatic, estrogen and androgen receptor positive, breast cancer. Final results of the primary endpoint and current progression free survival. Cancer Research 75 (Supplement) Ab P1-13-04. (doi:10.1158/1538-7445.SABCS14-P1-13-04)

Palmieri C, Januszewski A, Stanway S \& Coombes RC 2011 Irosustat: a first-generation steroid sulfatase inhibitor in breast cancer. Expert Review of Anticancer Therapy 11 179-183. (doi:10.1586/era.10.201)

Panet-Raymond V, Gottlieb B, Beitel LK, Pinsky L \& Trifiro MA 2000 Interactions between androgen and estrogen receptors and the effects on their transactivational properties. Molecular and Cellular Endocrinology 167 139-150. (doi:10.1016/S0303-7207(00)00279-3)

Pannuti F, Martoni A, Lenaz GR, Piana E \& Nanni P 1978 A possible new approach to the treatment of metastatic breast cancer: massive doses of medroxyprogesterone acetate. Cancer Treatment Reports 62 499-504.

Park S, Koo J, Park HS, Kim JH, Choi SY, Lee JH, Park BW \& Lee KS 2010 Expression of androgen receptors in primary breast cancer. Annals of Oncology 21 488-492. (doi:10.1093/annonc/mdp510)
Perrault D, Eisenhauer EA, Pritchard KI, Panasci L, Norris B, Vandenberg T \& Fisher B 1996 Phase II study of the progesterone antagonist mifepristone in patients with untreated metastatic breast carcinoma: a National Cancer Institute of Canada Clinical Trials Group study. Journal of Clinical Oncology 14 2709-2712.

Peters AA, Buchanan G, Ricciardelli C, Bianco-Miotto T, Centenera MM, Harris JM, Jindal S, Segara D, Jia L, Moore NL, et al. 2009 Androgen receptor inhibits estrogen receptor-alpha activity and is prognostic in breast cancer. Cancer Research 69 6131-6140. (doi:10.1158/00085472.CAN-09-0452)

Peters AA, Ingman WV, Tilley WD \& Butler LM 2011 Differential effects of exogenous androgen and an androgen receptor antagonist in the peri- and postpubertal murine mammary gland. Endocrinology 152 3728-3737. (doi:10.1210/en.2011-1133)

Piccart M, Hortobagyi GN, Campone M, Pritchard KI, Lebrun F, Ito Y, Noguchi S, Perez A, Rugo HS, Deleu I, et al. 2014 Everolimus plus exemestane for hormone-receptor-positive, human epidermal growth factor receptor-2-negative advanced breast cancer: overall survival results from BOLERO-2dagger. Annals of Oncology 25 2357-2362. (doi:10.1093/annonc/mdu456)

Polley MY, Leung SC, McShane LM, Gao D, Hugh JC, Mastropasqua MG, Viale G, Zabaglo LA, Penault-Llorca F, Bartlett JM, et al. 2013 An international Ki67 reproducibility study. Journal of the National Cancer Institute 105 1897-1906. (doi:10.1093/jnci/djt306)

Poulin R, Simard J, Labrie C, Petitclerc L, Dumont M, Lagace L \& Labrie F 1989 Down-regulation of estrogen receptors by androgens in the ZR-75-1 human breast cancer cell line. Endocrinology 125 392-399. (doi:10.1210/endo-125-1-392)

Purdie CA, Quinlan P, Jordan LB, Ashfield A, Ogston S, Dewar JA \& Thompson AM 2014 Progesterone receptor expression is an independent prognostic variable in early breast cancer: a population-based study. British Journal of Cancer 110 565-572. (doi:10.1038/bjc.2013.756)

Ravdin PM, Green S, Dorr TM, McGuire WL, Fabian C, Pugh RP, Carter RD, Rivkin SE, Borst JR, Belt RJ, et al. 1992 Prognostic significance of progesterone receptor levels in estrogen receptorpositive patients with metastatic breast cancer treated with tamoxifen: results of a prospective Southwest Oncology Group study. Journal of Clinical Oncology 10 1284-1291.

Rechoum Y, Rovito D, Iacopetta D, Barone I, Ando S, Weigel NL, O'Malley BW, Brown PH \& Fuqua SA 2014 AR collaborates with ERalpha in aromatase inhibitor-resistant breast cancer. Breast Cancer Research and Treatment 147 473-485. (doi:10.1007/s10549-0143082-8)

Ren Q, Zhang L, Ruoff R, Ha S, Wang J, Jain S, Reuter V, Gerald W, Giri DD, Melamed J, et al. 2013 Expression of androgen receptor and its phosphorylated forms in breast cancer progression. Cancer 119 2532-2540. (doi:10.1002/cncr.28092)

Robertson JF, Willsher PC, Winterbottom L, Blamey RW \& Thorpe S 1999 Onapristone, a progesterone receptor antagonist, as first-line therapy in primary breast cancer. European Journal of Cancer $\mathbf{3 5}$ 214-218. (doi:10.1016/S0959-8049(98)00388-8)

Robertson JF, Lindemann JP, Llombart-Cussac A, Rolski J, Feltl D, Dewar J, Emerson L, Dean A \& Ellis MJ 2012 Fulvestrant 500 mg vs anastrozole $1 \mathrm{mg}$ for the first-line treatment of advanced breast cancer: follow-up analysis from the randomized 'FIRST' study. Breast Cancer Research and Treatment 136 503-511. (doi:10.1007/ s10549-012-2192-4)

Robinson JL, Macarthur S, Ross-Innes CS, Tilley WD, Neal DE, Mills IG \& Carroll JS 2011 Androgen receptor driven transcription in molecular apocrine breast cancer is mediated by FoxA1. EMBO Journal 30 3019-3027. (doi:10.1038/emboj.2011.216)

Robinson DR, Wu YM, Vats P, Su F, Lonigro RJ, Cao X, Kalyana-Sundaram S, Wang R, Ning Y, Hodges L, et al. 2013 Activating ESR1 mutations in hormone-resistant metastatic breast cancer. Nature Genetics 45 1446-1451. (doi:10.1038/ng.2823) 
Romieu G, Maudelonde T, Ulmann A, Pujol H, Grenier J, Cavalie G, Khalaf S \& Rochefort H 1987 The antiprogestin RU486 in advanced breast cancer: preliminary clinical trial. Bulletin du Cancer $\mathbf{7 4} 455-461$.

Ross-Innes CS, Stark R, Teschendorff AE, Holmes KA, Ali HR, Dunning MJ, Brown GD, Gojis O, Ellis IO, Green AR, et al. 2012 Differential oestrogen receptor binding is associated with clinical outcome in breast cancer. Nature 481 389-393. (doi:10.1038/nature10730)

Schneider C, Jick SS \& Meier CR 2009 Risk of gynecological cancers in users of estradiol/dydrogesterone or other HRT preparations. Climacteric 12 514-524. (doi:10.3109/13697130903075352)

Schoenfeld W, Zweifel M, Thuerlimann B, Riniker S, Weder P, von Moos R, Pagani O, Bigler M, Rothgiesser KMM, Pilop C, et al. 2015 Phase 1 evaluation of the androgen receptor modulator CR1447 in patients with advanced breast cancer (SAKK 21/12) (abstract). Cancer Research 74 (Supplement) Ab P5-14-05. (doi:10.1158/1538-7445. SABCS15-P5-14-05)

Sikora MJ, Cordero KE, Larios JM, Johnson MD, Lippman ME \& Rae JM 2009 The androgen metabolite 5alpha-androstane-3beta,17beta-diol (3betaAdiol) induces breast cancer growth via estrogen receptor: implications for aromatase inhibitor resistance. Breast Cancer Research and Treatment 115 289-296. (doi:10.1007/s10549-008-0080-8)

Sikora MJ, Strumba V, Lippman ME, Johnson MD \& Rae JM 2012 Mechanisms of estrogen-independent breast cancer growth driven by low estrogen concentrations are unique vs complete estrogen deprivation. Breast Cancer Research and Treatment 134 1027-1039. (doi:10.1007/s10549-012-2032-6)

Simanainen U, Gao YR, Walters KA, Watson G, Desai R, Jimenez M \& Handelsman DJ 2012 Androgen resistance in female mice increases susceptibility to DMBA-induced mammary tumors. Hormones and Cancer 3 113-124. (doi:10.1007/s12672-012-0107-9)

Simpson ER 2003 Sources of estrogen and their importance. Journal of Steroid Biochemistry and Molecular Biology 86 225-230. (doi:10.1016/ S0960-0760(03)00360-1)

Spoerke JM, Gendreau S, Walter K, Qiu J, Wilson TR, Savage H, Aimi J, Derynck MK, Chen M, Chan IT, et al. 2016 Heterogeneity and clinical significance of ESR1 mutations in ER-positive metastatic breast cancer patients receiving fulvestrant. Nature Communications 7 11579. (doi:10.1038/ncomms11579)

Stanway SJ, Purohit A, Woo LW, Sufi S, Vigushin D, Ward R, Wilson RH, Stanczyk FZ, Dobbs N, Kulinskaya E, et al. 2006 Phase I study of STX 64 (667 Coumate) in breast cancer patients: the first study of a steroid sulfatase inhibitor. Clinical Cancer Research 12 1585-1592. (doi:10.1158/1078-0432.CCR-05-1996)

Stoll BA 1967 Progestin therapy of breast cancer: comparison of agents. BMJ 3 338-341. (doi:10.1136/bmj.3.5561.338)

Stone A, Zotenko E, Locke WJ, Korbie D, Millar EK, Pidsley R, Stirzaker C, Graham P, Trau M, Musgrove EA, et al. 2015 DNA methylation of oestrogen-regulated enhancers defines endocrine sensitivity in breast cancer. Nature Communications 6 7758. (doi:10.1038/ncomms8758)

Thangavel C, Dean JL, Ertel A, Knudsen KE, Aldaz CM, Witkiewicz AK, Clarke R \& Knudsen ES 2011 Therapeutically activating RB: reestablishing cell cycle control in endocrine therapy-resistant breast cancer. Endocrine-Related Cancer 18 333-345. (doi:10.1530/ERC-10-0262)

Tormey DC, Lippman ME, Edwards BK \& Cassidy JG 1983 Evaluation of tamoxifen doses with and without fluoxymesterone in advanced breast cancer. Annals of Internal Medicine 98 139-144. (doi:10.7326/0003-4819-98-2-139)

Toy W, Shen Y, Won H, Green B, Sakr RA, Will M, Li Z, Gala K, Fanning S, King TA, et al. 2013 ESR1 ligand-binding domain mutations in hormone-resistant breast cancer. Nature Genetics $\mathbf{4 5}$ 1439-1445. (doi:10.1038/ng.2822)
Traina TA, Yardley DA, Patel MR, Schwartzberg LS, Elias A, Gucalp A, Blaney ME, Gibbons J, Hudis CA \& LoRusso P 2014 A phase 1 open-label study evaluating the safety, tolerability, and pharmacokinetics of enzalutamide alone or combined with an aromatase inhibitor in women with advanced breast cancer. Annals of Oncology 25 (Supplement 1) i4. (doi:10.1093/annonc/mdu064.1)

Traina TA, Miller K, Yardley DA, O'Shaughnessy J, Cortes J, Awada A, Kelly CM, Trudeau ME, Schmid P, Gianni L, et al. 2015 Results from a phase 2 study of enzalutamide (ENZA), an androgen receptor (AR) inhibitor, in advanced AR+ triple-negative breast cancer (TNBC). Journal of Clinical Oncology 33 (Supplement) Ab 1003. (doi:10.1158/1538-7445.SABCS14-P5-19-09)

Tran C, Ouk S, Clegg NJ, Chen Y, Watson PA, Arora V, Wongvipat J, Smith-Jones PM, Yoo D, Kwon A, et al. 2009 Development of a second-generation antiandrogen for treatment of advanced prostate cancer. Science 324 787-790. (doi:10.1126/science.1168175)

Turner NC, Ro J, Andre F, Loi S, Verma S, Iwata H, Harbeck N, Loibl S, Huang Bartlett C, Zhang K, et al. 2015 Palbociclib in hormone-receptor-positive advanced breast cancer. New England Journal of Medicine 373 209-219. (doi:10.1056/NEJMoa1505270)

Ulrich P 1939 Testosterone (hormone male) et son role possible dans le traitment de certains cancers du sein. ACTA: Unio Internationalis Contra Cancrum 4 377-379.

van Veelen H, Willemse PH, Tjabbes T, Schweitzer MJ \& Sleijfer DT 1986 Oral high-dose medroxyprogesterone acetate vs tamoxifen. A randomized crossover trial in postmenopausal patients with advanced breast cancer. Cancer 58 7-13. (doi:10.1002/10970142(19860701)58:1<7::AID-CNCR2820580103>3.0.CO;2-\#)

Viale G, Regan MM, Maiorano E, Mastropasqua MG, Dell'Orto P, Rasmussen BB, Raffoul J, Neven P, Orosz Z, Braye S, et al. 2007 Prognostic and predictive value of centrally reviewed expression of estrogen and progesterone receptors in a randomized trial comparing letrozole and tamoxifen adjuvant therapy for postmenopausal early breast cancer: BIG 1-98. Journal of Clinical Oncology 25 3846-3852. (doi:10.1200/JCO.2007.11.9453)

Westerberg H 1980 Tamoxifen and fluoxymesterone in advanced breast cancer: a controlled clinical trial. Cancer Treatment Reports 64 117-121.

Witzel I, Graeser M, Karn T, Schmidt M, Wirtz R, Schutze D, Rausch A, Janicke F, Milde-Langosch K \& Muller V 2013 Androgen receptor expression is a predictive marker in chemotherapy-treated patients with endocrine receptor-positive primary breast cancers. Journal of Cancer Research and Clinical Oncology 139 809-816. (doi:10.1007/ s00432-013-1382-8)

Yamaoka M, Hara T, Hitaka T, Kaku T, Takeuchi T, Takahashi J, Asahi S, Miki H, Tasaka A \& Kusaka M 2012 Orteronel (TAK-700), a novel non-steroidal 17,20-lyase inhibitor: effects on steroid synthesis in human and monkey adrenal cells and serum steroid levels in cynomolgus monkeys. Journal of Steroid Biochemistry and Molecular Biology 129 115-128. (doi:10.1016/j.jsbmb.2012.01.001)

Yamaoka M, Hara T, Araki H, Kaku T, Hitaka T, Tasaka A \& Kusaka M 2013 Effect of an investigational CYP17A1 inhibitor, orteronel (TAK-700), on estrogen- and corticoid-synthesis pathways in hypophysectomized female rats and on the serum estradiol levels in female cynomolgus monkeys. Journal of Steroid Biochemistry and Molecular Biology 138 298-306. (doi:10.1016/j.jsbmb.2013.07.002)

Yu Q, Niu Y, Liu N, Zhang JZ, Liu TJ, Zhang RJ, Wang SL, Ding XM \& Xiao XQ 2011 Expression of androgen receptor in breast cancer and its significance as a prognostic factor. Annals of Oncology 22 1288-1294. (doi:10.1093/annonc/mdq586)

Zava DT \& McGuire WL 1977 Estrogen receptors in androgen-induced breast tumor regression. Cancer Research 37 1608-1610.

Received in final form 6 October 2016

Accepted 11 October 2016

Accepted Preprint published online 11 October 2016 http://erc.endocrinology-journals.org DOI: $10.1530 /$ ERC-16-0427
(C) 2016 Society for Endocrinology Printed in Great Britain 